\title{
Corrective Feedbacks and Grammar Teaching in a Situated Teaching Context of Process-Based Writing
}

\author{
Hartono Hartono \\ Universitas Islam Sultan Agung \\ hartono@unissula.ac.id \\ Choiril Anwar \\ Universitas Islam Sultan Agung \\ choirilanwar@unissula.ac.id \\ Afina Murtiningrum \\ Universitas Islam Sultan Agung \\ DOI: http://dx.doi.org/10.18326/rgt.v12i1.28-48
}

Submission
Track:
Received:
22/04/2019
Final Revision:
21/05/2019
Available online:
01/06/2019
Corresponding
Author:
Hartono Hartono,
hartono@ unissula.ac.id

\begin{abstract}
This study was aimed at finding out 1) how learners in a specific teaching-learning context namely process-based academic essay writing perceived the importance of corrective feedbacks $(C F) ; 2)$ what $C F$ was expected the most; 3$)$ in what way learners preferred to have their CF provided; and 4) how learners perceived the importance of grammar teaching. It was conducted at English Literature Department of a university in Central Java Indonesia. Forty-two students who were taking Essay Writing course served as the subjects for the study. The course itself was delivered in a process-based writing in which content development and rhetoric were given more emphasis than grammar accuracy was. Data for the study were collected by questionnaire and a semi-structured interview with 5 guided questions. The findings suggest that learners still considered CFs as important and useful for their writing improvement. Learners expected to have comprehensive CFs of grammar, vocabulary, spelling, organization and punctuation, and CF on grammar was the most preferred one. In terms of CF provision technique, underlying and making notes were the most preferred techniques. Even though it was in a process-based writing classroom, grammar teaching was still perceived very important. Finally, this study concludes that the shift of approach from a product-based to a process-based did not significantly change learners' focus from forms to content.
\end{abstract}

Keywords: process-based approach, corrective feedbacks, grammar teaching, learners' perception 


\section{INTRODUCTION}

Providing corrective feedbacks (CF) is a common practice and function of writing teachers especially writing in a foreign or second language (Chen, Nassaji, \& Liu, 2016). Though it is a time consuming, tedious and painstaking task (Al-Jarrah, 2016; Ferris, 2002; Semke, 1984), teachers keep doing this since they believe that learners will be able to improve their writing with their feedback. Theoretically, feedbacks have roles in both second language learning and language pedagogy. Behaviorist and cognitive theories suggest that feedbacks contribute to language learning, while structural and communicative approaches view feedbacks as a means of fostering learners' motivation and ensuring linguistic accuracy (Ellis, 2009). Feedback is provided not only for the purpose of assessment but also for assisting learners to work out of text's potential. It assists learners to comprehend the writing context and to provide a sense of audience and their expectation of the texts (Hyland \& Hyland, 2006a). It contributes to learners' progress, the engagement of students in learning process, and the revision responses expected from the learners (Parr \& Timperley, 2010). Feedback provision may also serve as a means of creating effective teacher-learner and learner-learner interactions in teaching-learning context which finally can trigger revisions for language improvement (Hyland, 1998; Seker \& Dincer, 2014).

Broadly defined, CF is a response to a learner's utterance that contains error (Ellis \& Sheen, 2006), while written corrective feedback (WCF) is a written response to a linguistic errors, either provided directly or indirectly, that has been made in the writing of a text by an L2 learner (Yamashita, 2017). Direct WCF is the provision of correct linguistic forms or structure by the teacher, while indirect WCF is the provision of indication (through a symbol or an abbreviation) to the learners that an error has been made (Storch, 2010). Feedback can have motivational and informational meanings. Motivationally, it affects the effort made by the learners, while informationally it tells learners the need to change their performance towards a particular direction. Besides, it serves as re-inforcement by which rewards and/or punishment might be administered (Ravand \& Rasekh, 2011).

Although, CF has become a common practice and a hot topic of study in second/foreign language writing for such a long time, the debate over its effectiveness in improving learners' writing accuracy just started in 1996 with the publication of Truscott's work on the case against grammar correction (Truscott, 1996). Truscott has made a very strong claim that grammar correction is useless and should be eliminated from classroom practice because it has no empirical grounds on its effectiveness both practically and theoretically. Ferris (Ferris, 
1999), however, keeps arguing that there have been a lot of research findings which show that error corrections can and do help. Though the debate on its effectiveness is still going on until these days, the results remain inconclusive (Alimohammadi \& Nejadansari, 2014; Bitchener \& Knoch, 2009; Bitchener, Young, \& Cameron, 2005; Diab, 2005; Hyland, 1998; Hyland \& Hyland, 2006a; Jusa \& Kuang, 2016; Karim \& Nassaji, 2015; Maharani, 2017; Storch, 2010; Vyatkina, 2011; Wahyuni, 2017).

Research in CF so far has been directed to at least 2 areas. The first area investigates the effectiveness of the CF both by the proponents which claim that providing CF is significant in improving learners' writing (Bitchener, 2008; Bitchener \& Knoch, 2009; Bitchener et al., 2005; Chandler, 2003; Ellis, 2009; Ferris, 1999; K. Hyland \& Hyland, 2006a; Nakanishi, 2007), and by the opponents which claim that CF is not significant even harmful for learning (Kepner, 1991; Liu \& Carless, 2006; Polio, Fleck, \& Leder, 1998; Semke, 1984; Shin, 2008; Truscott, 1996, 2007). The second area, rather than measuring its effectiveness, focuses the learners' perception and preferences on it; how learners perceive $\mathrm{CF}$ and what types of $\mathrm{CF}$ learners mostly expect to have to improve their writing (Amrhein \& Nassaji, 2010; Black \& Nanni, 2016; A. V. Brown, 2009; Chen et al., 2016; Diab, 2005; Ghanbari, Amiramini, \& Shamsoddini, 2014; Karim \& Nassaji, 2015; Park, 2010; Seker \& Dincer, 2014). Researchers in this area believe that learners' preference is important to be investigated to avoid teachers being misled by their own perceptions since students may construe instructional techniques in different ways than the teacher may have expected (Chen et al., 2016). In addition, teaching and learning will be more effective if there is no gap between what teachers do and what the learners expect. The gap will trigger learners' discontent on the learning which further may impair the learning process itself (Brown, 2009).

Different learning and situational contexts have made the results of research on teachers' and learners' perceptions and preferences on CF different. Mostly, learners perceived that CF was useful for their language improvement and help them write better (Karim \& Nassaji, 2015; Listiani, 2017; Seker \& Dincer, 2014). Learners found out that WCF is an important aspect of their language learning experience because it can help them identify the recurring errors, provide opportunities for writing improvement, and help them give attention on language form and accuracy (Chen et al., 2016; Diab, 2005). Research also found that learners considered teachers' feedback more important than other types of feedbacks (Amrhein \& 
Nassaji, 2010), and that learners' preference and teachers' practice in providing CF were not much different (Lee, 2005). Learners were satisfied with CFs and wanted to have more because they facilitated their learning (Ghanbari et al., 2014).

Concerning the types of errors to be corrected, studies found that students are varied in terms of preference (Black \& Nanni, 2016; Lee, 2005), but mostly they had positive perception about the corrections of form-focused errors such as grammatical errors, punctuation errors, spelling errors, and vocabulary errors rather than content-focused errors (Amrhein \& Nassaji, 2010; Ashwell, 2000; Hyland, 2003; Nanni \& Black, 2017). Other studies found that students prefer to have content-related feedback (Semke, 1984) and to have a comprehensive error feedback.

Previous research on learners' preference on CF was mostly conducted under a general setting of teaching and learning. The study of Chen at al. (2016) for example, was conducted in a public university, while Karim and Nassaji (2015) conducted a study in a general English classes of intermediate level. Similarly, the study of Seker and Dincer (2014) was conducted in a preparatory education before students start studying university. This present study was different because it was conducted under a specific teaching-learning context namely processapproach writing where for one semester students were taught writing on academic essays by applying a process-based approach from planning, drafting, revising and writing for the final product.

By definition, process-approach writing is an approach to writing in which learners focus more on their process of writing, what the writers do, rather than on their would-be-finished product look like. In the end, learners finally have to finish and have a written product, yet each step in the writing process itself gets more emphasis. By focusing on the process of writing, learners are expected to understand themselves better, and find how to work through the writing (Onozawa, 2010). Students' ability in developing and organizing ideas or the rhetoric through the writing process is emphasized more than in other writing approach. This approach was born in L1 context in North American universities when writing teachers realized that their students needed to have another type of attention and instruction not just simply a final product (Hyland \& Hyland, 2006b). In a process approach, writing is treated as a creative act and a thinking process, a writer produces a final written product based on his thinking after going through a series of thinking activities (Brown, 2001). 
There have been some studies investigating the effectiveness of process-based writing in improving learners' writing competence. It was found that process-based writing approach had a great impact on the writing skill of learners and reduce their writing anxiety (Arici \& Kaldirim, 2015). Process approach writing could change the students' negative attitude and behavior towards writing (Setyono, 2014), and improved writing ability and enhanced students' socio-cognitive development (Ho, 2006; Puengpipattrakul, 2014; Rohmatika, 2014). The present study is significant because understanding the students' preference and perception in learning from a situated perspective will help teachers to provide feedback on a specific context by identifying what students need and prefer under specific setting and contextual constraints of learning context (Amrhein \& Nassaji, 2010; Hyland \& Hyland, 2006a). Furthermore, as suggested by Hyland, students' involvement in the decision making is important and needs to be acknowledged so that teachers can view students as active agents who are able to construct the terms and conditions of their own learning, respond and adapt their writing and revision strategies based on the feedback they receive (Hyland, 2010). This is what referred as the humanistic aspect of writing teaching assessment (Hamp-lyons, 2008).

Under this perspective, the study was conducted to answer the following research questions: (1) How did learners in a process-based academic essay writing class perceive the importance of corrective feedbacks? (2) What corrective feedbacks did learners in a processbased academic essay writing class expect most? (3) In what way did learners in a processbased academic essay writing class prefer to have their CF from the teachers? and (4) How did learners in a process-based academic essay writing class perceive the importance of grammar teaching?

\section{RESEARCH METHOD}

\section{Setting and participants}

The study was conducted at English Literature Department of a university in Central Java Indonesia. Forty-two students taking Essay Writing Course were selected as the participants of the study. They were grouped into two small classes with 21 students each, namely Literature 1 (L1) and Literature 2 (L2). The small size of the class was intended to facilitate better learning environment. One of the researchers was the lecturer of the course for the whole semester. The course actually came after two previous writing courses namely 
Intensive Course for Writing during their first semester, Paragraph-Based Writing during their second semester. The class met once a week for 90 minutes but the students had a lot of writing assignments to be done independently outside the classroom.

Since the first day of the course, the students had been informed that the course would adopt process-based writing which involved planning, drafting, revising and final draft. In almost every week, students had to submit their work based on the progress of the process. The submitted work would be reviewed by the lecturer and returned to the students for improvement. Feedbacks on various kinds were provided for them in the forms of comments, questions, cross signs, underlines, etc. written in the students' papers and some were presented orally during the class session. In certain occasions, direct feedbacks were given, in the other occasions indirect feedbacks were chosen to replace the direct method. When students did not happen to understand the correct and appropriate forms of language, content or organization, the lecturer explained them in the classroom or asked the students to see the lecturer for discussion and explanation during class hours. Students then revised the draft based on the feedbacks they received and resubmitted it to the lecturer together with their previous draft so that the lecturer could check what students did with the CF.

The course covers topics of general description of essays, how to write essays, and essay writing practices of different genres as description, explanation, compare-contrast, causeeffect, and argumentation. Final grading was based the students' portfolio which consisted of the final draft and all previous and corrected drafts.

\section{Instrument}

Data for the study were collected by questionnaire and interviews. The questionnaire adopted the items used by Chen et al. with modification (Chen et al., 2016). It was designed in two parts and for the sake of comprehensibility and practicality was written in Indonesian language as the mother tongue of the students. The first part collected information about the respondents' personal information as name, study program, semester, and gender, while the second part consisted of 8 items. The first one collected information about respondents' perception about the importance of grammar teaching. It was presented on 7 statements requiring responses in Likert-type scales of agreement from "Strongly Disagree" to "Strongly Agree". Item indicating that grammar teaching was not important was reversely scored. The second item collected information on respondents' perception on the importance of CF with 5 
options from "Absolutely Unimportant" to "Absolutely Important". Item 3 collected information on respondents' most preferred CF with 5 options of grammar, vocabulary, spelling, organization, and punctuation. Item 4 dealt with what respondents expected their lecturers to do when there were many errors in their writing. Item 5 inquired respondents' preference on technique on CF provision. Item 6 collected respondents' opinion dealing with the importance of long comments made by the lecturers. Item 7 was about respondents' opinion on the importance of lecturer's comments on content, grammar, organization, and overall quality, while the last item was about what respondents would do with the CF.

For the semi-structured interview, 5 questions were used as guides. They were about the importance of grammar skill for writing, the benefits of having $\mathrm{CF}$, the most preferred $\mathrm{CF}$ type, respondents' follow up on $\mathrm{CF}$, and respondents' preference of direct vs. indirect CF. Under consideration of representativeness and practicality, the interviews were conducted with only 7 students who were selected from the population using systematic random sampling. The purpose for the interview was to explore their further opinions and reasons of the preferences as well as their wider perspective about the topic. Students' responses were transcribed. Data from the questionnaires were analyzed descriptively, while data of interview transcripts were analyzed interpretatively in relation to the information collected.

\section{FINDINGS AND DISCUSSION}

\section{Result}

\section{a. The importance of CFs}

The first part of the questionnaire includes data about the respondents' perception on the importance of $\mathrm{CF}$ covering 6 statements namely the importance of $\mathrm{CF}$ in general, $\mathrm{CF}$ with long and detailed comments, $\mathrm{CF}$ on content, $\mathrm{CF}$ on grammar, $\mathrm{CF}$ on organization, and $\mathrm{CF}$ on the writing quality as a whole. The respondents rated the importance of those items in 5 scales of importance "Absolutely not Important", "Not Important", "No Comment", "Important", and "Very Important" which were scored 1 to 5 respectively. The results were presented in Table 1. 
Table 1. Respondents' Perception on the Importance of CFs

\begin{tabular}{|c|c|c|c|c|c|c|c|}
\hline No & Items & $\mathrm{N}$ & $\underset{\mathrm{m}}{\operatorname{Minimu}}$ & $\begin{array}{l}\text { Maximu } \\
\mathrm{m}\end{array}$ & Mean & $\begin{array}{c}\text { Std. } \\
\text { Deviatio } \\
\mathrm{n}\end{array}$ & Category \\
\hline 1 & $\begin{array}{l}\text { The importance of CF in } \\
\text { general }\end{array}$ & 42 & 3.00 & 5.00 & 4.12 & .74 & High \\
\hline 2 & $\begin{array}{l}\text { The importance of CF with } \\
\text { long \& detailed comments. }\end{array}$ & 42 & 1.00 & 5.00 & 3.86 & .89 & High \\
\hline 3 & $\begin{array}{l}\text { The importance of CF on } \\
\text { content }\end{array}$ & 42 & 2.00 & 5.00 & 4.19 & .86 & High \\
\hline 4 & $\begin{array}{l}\text { The importance of CF on } \\
\text { grammar }\end{array}$ & 42 & 2.00 & 5.00 & 4.17 & .79 & High \\
\hline 5 & $\begin{array}{l}\text { The importance of CF on } \\
\text { organization }\end{array}$ & 42 & 1.00 & 5.00 & 4.21 & .78 & High \\
\hline \multirow[t]{2}{*}{6} & $\begin{array}{l}\text { The importance of CF on the } \\
\text { writing quality as a whole }\end{array}$ & 42 & 3.00 & 5.00 & 4.21 & .68 & High \\
\hline & Valid N (list wise) & 42 & & & & & \\
\hline
\end{tabular}

The categorization to "High", "Moderate", and "Low" as in Table 1 was based on the hypothetical means where mean scores lower than 2.36 (the score of hypothetical means minus standard deviation) were categorized as "low", while the scores above 3.66 (the score of hypothetical means plus standard deviation) were categorized as "high". The mean scores between these two were categorized as "moderate". The results as presented in Table 1 show that most of respondents perceived CFs as highly important. Of the 6 items, 5 of them had mean scores above 4 in which CF on organization and on the writing quality as a whole had the highest mean scores (4.21).

Respondents believed it was very important to get feedbacks in terms of his/her writing organization. In other words, they needed to know whether their ideas were structurally organized. In a process-based writing, organization is an aspect which is given much emphasis (Onozawa, 2010), therefore, it is very good that learners were wondering whether they had been able to do well or not by expecting feedbacks. A well-organized writing helps readers follows the ideas; therefore, it is important to get feedbacks for improvement.

Item 2 namely CF with long \& detailed comments had the lowest mean score (3.86). It is understandable because most writers actually do not expect long and detailed comments. All they need are simple comments and suggestion so that they can know what to do to improve 
the writing. For some, long comments are more irritating than helping. An overwhelming comment is frustrating and may lead to the lowering of their self-confidence.

\section{b. Mostly preferred CFs}

Data of mostly preferred CF were collected by 3 items of questionnaire namely 1) types of CF mostly preferred by respondents with 5 options of grammar, vocabulary, spelling, organization, and punctuation. Secondly, it was the mostly preferred correction. If there were many errors in the writing, what the respondents expected their lecturer to do with the errors/mistakes. This item was set with options that lecturer should a) correct all the errors/ mistakes, b) correct the major errors/mistakes, c) correct the errors/mistakes which influence the ideas being communicated, and d) only correct content errors/mistakes and ignore grammar errors/mistakes. The third was about the mostly preferred technique of CF provision with options of a) underlying without correction, b) underlying and making notes on reference for correction, c) only specifying the errors/mistakes but not correcting, d) indicating the errors/mistakes and specifying them, and e) underlying the errors/mistakes and correcting them, f) correcting and explaining the errors/mistakes, g) making cross sign ( $\mathrm{x}$ ) next to the errors/mistakes without correcting, and h) suggesting to get help from friends. The results are presented in Table 2.

Table 2. Mostly Preferred CF and their Provision Techniques

\begin{tabular}{|c|c|c|c|c|}
\hline No & Item & Options Provided & $\begin{array}{c}\text { Number } \\
\text { of } \\
\text { Response }\end{array}$ & Percent \\
\hline \multirow[t]{5}{*}{1} & Mostly & Grammar & 34 & 80.95 \\
\hline & preferred & Vocabulary & 5 & 11.91 \\
\hline & CF type & Spelling & 0 & 0 \\
\hline & & Organization & 3 & 7.14 \\
\hline & & Punctuation & 0 & 0 \\
\hline \multirow[t]{4}{*}{2} & Mostly & correcting all the errors/mistakes & 32 & 76.19 \\
\hline & preferred & correcting the major errors/mistakes & 5 & 11.91 \\
\hline & way of & correcting the errors/mistakes which influence ideas & 3 & 7.14 \\
\hline & correction & $\begin{array}{l}\text { only correcting content errors/mistakes and ignore } \\
\text { grammar }\end{array}$ & 2 & 4.76 \\
\hline \multirow[t]{2}{*}{3} & mostly & underlying without correction & 2 & 4.76 \\
\hline & $\begin{array}{l}\text { preferred } \\
\text { technique }\end{array}$ & $\begin{array}{l}\text { underlying and making notes on reference for } \\
\text { correction }\end{array}$ & 10 & 23.81 \\
\hline
\end{tabular}




\begin{tabular}{llcr}
$\begin{array}{ll}\text { of } \\
\text { feedback } \\
\text { provision }\end{array}$ & $\begin{array}{l}\text { only specifying the errors/mistakes but not } \\
\text { correcting }\end{array}$ & 0 & 0 \\
& indicating the errors/mistakes and specifying them & 8 & 19.05 \\
& underlying and correcting the errors/mistakes & 12 & 28.57 \\
& correcting and explaining the errors/mistakes & 8 & 19.05 \\
& making cross sign (x) without correcting & 0 & 0 \\
& suggesting to get help from friends & 2 & 4.76 \\
\hline
\end{tabular}

For the first, the data in Table 2 show that grammar CF was the first mostly preferred correction by having $80.95 \%$ of respondents. The second mostly preferred CF was vocabulary by having $11.91 \%$ respondents. Three respondents $(7.14 \%)$ chose to have organization $\mathrm{CF}$ as the most preferred one, while no respondent chose CF on spelling and punctuation. The data suggest that for the respondents grammar was an important issue in writing so that they had an extra attention on it. Correction on it was the highest priority. This finding was in line with the previous data that grammar correction was the most demanding.

For item 2, correcting all the errors/mistakes had become the most preferred correction the respondents expected from their lecturer. This option was chosen by 32 respondents (76.19\%). Correcting only the major errors/mistakes was preferred by $11.91 \%$ of the respondents, while two other ways of correction (correcting the errors/mistakes which influence ideas and only correcting content errors/mistakes and ignore grammar) were preferred by only few respondents.

For item 3 of the technique of error correction, the three most preferred ways were underlying and correcting the errors/mistakes (28.57\%), underlying and making notes on reference for correction (23.81\%), indicating the errors and specifying them and correcting and explaining each was chosen by 8 respondents (19.05\%). Suggesting to get help from friends was chosen by only 2 respondents, while only specifying the errors/mistakes but not correcting and making cross sign (x) without correcting were chosen by no respondent. The very small number of respondents chose "suggesting to get help from friends" may mean that the potential CF to trigger learner-learner interactions (F. Hyland, 1998; Seker \& Dincer, 2014) did not really materialize.

\section{c. The importance of grammar teaching}

The third part of the questionnaire was about respondents' perceptions of grammar teaching. It has 7 items of statement (from "a" to "g") requiring responses on the basis of their agreement. The result is presented in Table 3. 
Table 3. Descriptive Statistics of Respondents' Perception on the Importance of Grammar Teaching

\begin{tabular}{|c|c|c|c|c|c|c|}
\hline & & $\mathrm{N}$ & Minimum & Maximum & Mean & $\begin{array}{c}\text { Std. } \\
\text { Deviation }\end{array}$ \\
\hline \multicolumn{2}{|c|}{ Score total } & 42 & 18.00 & 31.00 & 25.17 & 2.95 \\
\hline \multicolumn{2}{|c|}{ Valid N (list wise) } & 42 & & & & \\
\hline \multicolumn{7}{|c|}{ Category } \\
\hline \multicolumn{2}{|r|}{ Category } & Frequency & y Percent & $\begin{array}{c}\text { Valid } \\
\text { Percent }\end{array}$ & \multicolumn{2}{|c|}{ Cumulative Percent } \\
\hline \multirow[t]{3}{*}{ Valid } & Moderate & 22 & 52.4 & 52.4 & \multicolumn{2}{|c|}{52.4} \\
\hline & High & 20 & 47.6 & 47.6 & \multicolumn{2}{|c|}{100.0} \\
\hline & Total & 42 & 100.0 & 100.0 & & \\
\hline
\end{tabular}

Table 3 shows that the minimum score in the descriptive statistics is 18 , and the maximum is 31 , while the mean and standard deviation are 25.17 and 2.95 respectively. For further analysis, the data were then categorized into 3 levels of perception of "Low", "Moderate", and "High" by using hypothetical mean and standard deviation. Respondents having low perception of grammar importance are those with total score lower than 16.44 , while for those having scores above 25.66 are categorized into having high perception of importance. Respondents with moderate perception of grammar importance, therefore, are those with scores standing between the low and the high. As a result, overall it was found that the respondents of the research had moderate perception about the importance of grammar teaching but with a very close score to high level.

The item analysis is presented in Table 4. It displays the mean score of each item from (a) to (g) as the following:

Table 4. Items' Mean Scores of Grammar Teaching Importance

\begin{tabular}{|c|c|c|c|}
\hline No & Statements & $\begin{array}{l}\text { Mean } \\
\text { Score }\end{array}$ & Category \\
\hline a. & Grammar course is important to master writing skills. & 4.19 & High \\
\hline b. & Learning grammar improves my skills in writing. & 4.02 & High \\
\hline c. & $\begin{array}{l}\text { I believe that my writing skill will improve quickly if I learn } \\
\text { and practice grammar. }\end{array}$ & 3.85 & High \\
\hline d. & I like to study grammar & 3.14 & Moderate \\
\hline e. & I need more grammar teaching in writing class. & 3.88 & High \\
\hline f. & I think of grammar rules when I am writing. & 3.48 & Moderate \\
\hline g. & $\begin{array}{l}\text { I think that practicing English in the real contexts is more } \\
\text { important than grammar learning. }\end{array}$ & 2.60 & Low \\
\hline
\end{tabular}


The data show that item (a) "Grammar course is important to master writing skills" has the highest mean score followed by item (b) which says that "Learning grammar improves my skills in writing". Item (c) which is about respondents' beliefs that learning and practicing grammar will improve writing skill and item (e) which describes respondents' need for grammar teaching in writing class also have high scores. These indicate that learning grammar is really important for those who like to improve their writing skills. Learners still firmly hold that grammar teaching correlates positively to writing skill. Consequently, they need a grammar course so that they are able to enhance their understanding on grammar by having discussion with the teacher as well as their classmates and consulting with the teacher about some complicated grammatical issues. On the contrary, item (g) which states that practicing English in the real contexts is more important than grammar learning has the lowest mean score. This is very consistent as they believe that when they want to be good at writing, mastering grammar is a must and cannot be substituted.

\section{d. The interview}

The semi structure interview was guided by six questions namely 1) the importance of grammar knowledge to develop English writing skills and why; 2) how the respondents responded when writing teacher talked about grammar in his class; 3) The usefulness of CF for respondents, why or why not; 4) The CF respondents expected most from their lecturer; 5) Respondents' follow-up on the CF, and 6) Respondents' preferred method of CF provision, between direct and indirect method. The interview was conducted in the lecturer's room in which interviewee was invited to see the interviewer one by one. The interview went on about five to seven minutes each.

For question number 1 regarding the respondents' perception about the importance of grammar knowledge to develop writing skill, the respondents stated that it was "very important" (6 respondents) and "important" (1 respondent). Some points of their arguments were: First, if grammar was wrong, the meaning would be questioned; Second, grammar correctness was about self-respect, students who wrote in poor grammar would be considered as not proficient in English; Third, students of English literature needed to learn English writing for business in which sentences had to be grammatically correct; Fourth, wrong grammar could mislead. Besides, there were still many students not mastering grammar; Fifth, without good grammar, writing would mean less. 
Respondents also did not object at all to their writing teacher talking about grammar in his class. Among the answers were: 1) Writing could be considered as a kind of grammar in practice and so far there were still many mistakes and errors of grammar in students' writing; 2) Writing in good grammar was very necessary; 3) Students still expected that their writing teachers explained or clarified grammar used in the writing; 4) Students needed to write intelligible texts and grammar accuracy was necessary; and 5) One of the criteria of good writing was accurate grammar. However, there was one respondent who was against the idea that a writing teacher presented grammar by saying that writing teacher had many other important things to address in his classroom.

For question on the usefulness of $\mathrm{CF}$, respondents stated that it was very useful on the following reasons: 1) With CF, students could know their mistakes/errors, how the sentences should have been and how to correct them; 2) It helped students learn more; 3) It could improve students' knowledge on grammar; 4) It informed students about their inappropriate grammar and encourages self-learning; 5) One of the respondent mentioned that he wanted to be a blogger whose writings were read by many people around the word. He wanted his writings were grammatically correct, therefore, he needed CF before the writings were published.

The interview also confirmed the data of the questionnaire that among other aspects of writing, grammar feedback was highly demanded. They mentioned some points as grammar accuracy contributed to the attractiveness of the writing, readers would feel disturbed reading texts with poor grammar, good writing was the one written in good grammar, incorrect grammar could mislead, and readers might not continue reading if the language was difficult to understand. One respondent claimed that content was the most important because in the content students laid their own ideas and imagination and many readers were interested in the content not the language.

As they got CFs, respondents claimed to do some of the following: reading, locating the errors/mistakes, finding references or learning, and rewriting. They mentioned that they felt fine even when their lectures gave them a lot of CFs. Concerning their preference on the way $\mathrm{CF}$ was presented between direct and indirect, some preferred to have it directly presented while the other preferred to have it indirectly. Those who preferred direct CF mentioned that they could learn better because they could really know the correct forms of the grammar. 
Besides, they had to rewrite the work as soon as possible while there were still many other things to do. Those who preferred to have indirect $\mathrm{CF}$ mentioned that indirect feedbacks encouraged better learning. Students could find their own ways to make the writings better as looking for reference or asking friends.

\section{Discussion}

This research was conducted to find out the answers of four research questions namely 1) how learners in a process-based academic essay writing class perceived the importance of corrective feedbacks, 2) the corrective feedbacks learners expected most, 3) their preference on feedback provision technique, and 4) how learners perceived the importance of grammar teaching. A process-based writing approach was adopted as a kind of variable of context of learning situation where it was expected that it would affect a different sense of learning. Contrary to a product-based approach, a process-based approach treats writing as a process rather than a product which evolves from planning, drafting, revising, and final product (Seow, 2002). In addition, idea and rhetorical development and organization are emphasized more than any other aspects of writing as grammar and lexical accuracies (Widodo, 2008). Therefore, it was important to see how learners adjusted themselves to the approach since the shift of learning focus would not be effective unless it was supported by the shift of learners' orientation.

For research question 1 based on a simple statistic descriptive analysis, the study found that CFs were perceived by students as highly important. This suggests that students can get benefits from the practice of feedbacks provision by their teachers to improve their language mastery. This finding is in line with previous studies as the one by Seker \& Dincer (2014) which suggested that students found feedbacks beneficial for their learning for their language improvement, by Chen et al. (2016) which discovered that students found feedbacks positive, by Karim \& Nassaji (2015) which indicated that feedbacks provided by lecturers were useful, and by Ghanbari et.al. (2014) which found that students believed that CF was effective and useful to improve their learning. In this study, all types of CFs were considered as highly important. This suggests that students were expecting to have a perfect writing work and their lecturers were expected to comment to all aspects of their writing. Though during the process of teaching and learning in the classroom, students were told that writing was a process and the quality of ideas presented would be valued higher than grammar accuracy, they still held 
that grammar CFs were very important. As it was revealed from the interview, students believed that they could get benefits by the provision of feedbacks as it could help them know the errors or mistakes they had made as well as how to correct them, encouraged them to learn more, and also improved their knowledge of grammar.

$\mathrm{CF}$ on grammar was the one that students expected mostly. This could be the result of their high perception of grammar importance in writing. Students were of the opinion that grammar was about the meaning since messages written in wrong grammar may mislead. One of the students even said that for those who wanted to have a job related to business, writing in correct grammar is important. Interestingly, based on the interview, there were also students who related the correctness of grammar in writing to self-respect of the writer. Ungrammatical sentences may implicate low self-respect because readers will easily judge that the writer was not competent. This may suggest that even though the course had adopted process-based approach in which idea development and organization were highly emphasized, students still held the traditional belief that writing was about grammar. This could be the effect of their previous learning experience. For years, many English classes have been occupied by the presentation and discussion of grammar. Vocabulary and organization were the second and third most preferred CF, while CFs on spelling and punctuation were not demanded at all. That no student demanded CF on spelling and punctuation could be attributed to the classroom practice. During the learning and teaching process, the lecturer did rarely provided CFs on those types because of the very errors /mistakes on them. Interestingly, $\mathrm{CF}$ on organization was not highly demanded although during learning activities in the classroom, this type of CFs was provided very often especially concerning the text coherences. Many students' writings were organized in loose connection between and among paragraphs, besides many thesis statements were not fully elaborated in the body.

Mostly, students preferred to have all errors/mistakes corrected than to have content or major errors only. For students, this expectation seemed fine but from lecturer's perspective, this practice could make students more dependent on the lecturer. Fulfilling the students' want is good, however, training and facilitating them to be independent learners who can find out their own solution to their problem would be better. Students' expectation that the errors should be directly corrected was based on the reasons that, as revealed from the interview, they could learn better because they knew exactly the correct forms of the mistakes. Students 
seemed to be "lazy" to find the right versions by themselves. The second reason was that they wanted to finish reworking quickly since they still had many other things to do. However, this kind of practice may not encourage them to do a more independent learning. Lecturers will also be overwhelmed with this task which may reduce their allocated time for doing other teaching activities.

Consistent to the previous set of data, the first most preferred technique of feedback provision was underlying and correcting the errors/mistakes. Secondly, it was underlying and making notes on reference for correction. The third and the fourth most preferred technique were indicating the errors/mistakes and specifying them, and correcting and explaining the errors/mistakes respectively. These four most preferred techniques could be grouped into two based directness and indirectness of the provision, as Table 2 shows, direct technique (correcting errors/mistakes directly) was preferred slightly more than the indirect one as by indicating the errors/mistakes without correcting or writing notes of reference.

For research question 4, the data show that learners' perception about the importance of grammar was moderate with the score close to high (25.17 to 25.66). This shows that for the writing learners, even when they were learning writing in a process-based approach, grammar was still considered to be an important aspect of writing, therefore, was valued highly. For the respondents observed in this study, the importance of studying grammar was functional in the sense that grammar mastery is important to master writing skill, learning grammar improves writing skill, and practicing grammar will improve writing skill. The motive of learning grammar was actually encouraged by the functionality of grammar in improving their writing. This is the contrary to emotional motive as the data show that item "e" in the questionnaire stating "I like to study grammar" which suggest the desire of studying grammar just because of "like" was rated only moderate. The finding that grammar is important in writing and foreign language learning in general is in line with a study of Pazaver \& Wang (2009) which found that students perceived the positive role of grammar in language instruction, and also the study of Ismail which indicated that students considered grammar instruction as important for language learning (Ismail, 2010). This high perception of grammar importance in writing had made students be able accept when writing lecturers talked about grammar. The processbased approach adopted during the instruction which emphasized more on the development of ideas and rhetoric had not changed the learners' perception on the importance of grammar 
because of learners' previous experience which presumably emphasized too much grammar accuracy in language.

\section{CONCLUSION}

The study finally concluded the answers to the four research questions set forth. Firstly, learners in a process-based academic essay writing class still perceived corrective feedbacks highly important and useful for improving their writing in second/foreign language. Secondly, learners expected to have grammar feedbacks the most since they believed that grammar accuracy in foreign language writing was not only about the meaning but also a selfrespect of the writers. Poor grammatical sentences implicated the writer's low competence in the language. Thirdly, learners preferred to have corrective feedbacks provided directly by showing them the correct versions of the errors or mistakes under the reason that they could easily know the correct forms of the mistake so that they could learn better. Fourthly, grammar teaching in a writing class was perceived important. For this reason, learners in writing class mostly did not have any objections when their lecturer talked about grammar during writing instruction. In the same time, grammar teaching was also rated highly important for learners since the learners believed that it could improve writing.

As a response to the failure of product-based approach, process-based approach offers challenges for both foreign/second writing lecturers and students. Lecturers need to find ways and strategies to deliver the approach effectively, while learners need to be more independent in learning. More research on these issues as the effectiveness of process-based approach, how learners perceive the effectiveness of the approach and the likes is, therefore, very urgent.

\section{ACKNOWLEDGEMENT}

The writers would like to express gratitude to Rector of Universitas Islam Sultan Agung (UNISSULA), Dean of the College of Languages and Communication Studies, Research Center of UNISSULA for their countless support. 


\section{REFERENCES}

Al-Jarrah, R. S. (2016). A suggested model of corrective feedback provision. Ampersand, 3, 98-107. https://doi.org/10.1016/j.amper.2016.06.003

Alimohammadi, B., \& Nejadansari, D. (2014). Written Corrective Feedback: Focused and Unfocused. Theory and Practice in Language Studies, 4(3), 581-587. https://doi.org/10.4304/tpls.4.3.581-587

Amrhein, H. R., \& Nassaji, H. (2010). Written corrective feedback: What do students and teachers prefer and why? Canadian Journal of Applied Linguistics, 13(2), 95-127.

Arici, A. F., \& Kaldirim, A. (2015). The effect of the process-based writing approach on writing success and anxiety of pre-service teachers. Anthropologist, 22(2), 318-327. https://doi.org/10.12738/estp.2014.3.1720

Ashwell, T. (2000). Patterns of Teacher Response to Student Writing in a Multiple-Draft Composition Classroom: Is Content Feedback Followed by Form Feedback the Best Method? Journal of Second Language Writing, 9(3), 227-257. https://doi.org/https://doi.org/10.1016/S1060-3743(00)00027-8

Bitchener, J. (2008). Evidence in support of written corrective feedback. Journal of Second Language Writing, 17(2), 102-118. https://doi.org/10.1016/J.JSLW.2007.11.004

Bitchener, J., \& Knoch, U. (2009). The value of a focused approach to written corrective feedback. ELT Journal, 63(3), 204-211. https://doi.org/10.1093/elt/ccn043

Bitchener, J., Young, S., \& Cameron, D. (2005). The effect of different types of corrective feedback on ESL student writing. Journal of Second Language Writing, 14(3), 191-205. https://doi.org/10.1016/j.jslw.2005.08.001

Black, D. A., \& Nanni, A. (2016). Written corrective feedback: Preferences and justifications of teachers and students in a Thai context. GEMA Online Journal of Language Studies, 16(3), 99-114. https://doi.org/10.17576/gema-2016-1603-07

Brown, A. V. (2009). Students' and Teachers' Perceptions of Effective Foreign Language Teaching: A Comparison of Ideals. The Modern Language Journal, 93(1), 46-60. https://doi.org/doi:10.1111/j.1540-4781.2009.00827.x

Brown, H. D. (2001). Teaching by principles: An interactive approach to language pedagogy (2nd ed.). New York: White Plains, Longman.

Chandler, J. (2003). The efficacy of various kinds of error feedback for improvement in the accuracy and fluency of L2 student writing. Journal of Second Language Writing, 12(3), 267-296. https://doi.org/10.1016/S1060-3743(03)00038-9

Chen, Si., Nassaji, H., \& Liu, Q. (2016). EFL learners' perceptions and preferences of written corrective feedback: a case study of university students from Mainland China. AsianPasific Journal of Second and Foreign Language Education, 1(5). https://doi.org/10.1186/s40862-016-0010-y

Diab, R. L. (2005). Teachers' and students' beliefs about responding to ESL writing: A case study. TESL Canada, 23(1), 28-43. https://doi.org/10.18806/tesl.v23i1.76

Ellis, R. (2009). Corrective feedback and teacher development. L2 Journal, 1(1), 2-18. https://doi.org/10.5811/westjem.2011.5.6700

Ellis, R., \& Sheen, Y. (2006). Reexamining the role of recasts in second language acquisition. Studies in Second Language Acquisition, 28(4), 575-600. https://doi.org/10.1017/S027226310606027X

Ferris, D. R. (1999). The case for grammar correction in L2 writing classes: A response to truscott (1996). Journal of Second Language Writing, 8(1), 1-11. https://doi.org/10.1016/S1060-3743(99)80110-6 
Ferris, D. R. (2002). Treatment of Error in Second-Language Student Writing. University of Michigan Press.

Ghanbari, B., Amiramini, S., \& Shamsoddini, M. R. (2014). HOW IRANIAN EFL LEARNERS PERCEIVE THE EFFECT OF WRITTEN CORRECTIVE FEEDBACK IN THEIR WRITING PERFORMANCE. Modern Journal of Language Teaching Methods ( MJLTM ), 4(4), 18-23.

Hamp-lyons, L. (2008). Best practice in writing assessment. In N. Saville \& L. Taylor (Eds.), Studies in Language Testing (27th ed., pp. 321-335). Cambridge University Press.

Ho, B. (2006). Using the Process Approach to Teach Writing in 6 Hong Kong Primary Classrooms. New Horizons in Education, (53), 22-41. Retrieved from http://eric.ed.gov/?id=EJ847597

Hyland, F. (1998). The impact of teacher written feedback on individual writers. Journal of Second Language Writing, 7(3), 255-286. https://doi.org/10.1016/S1060-3743(98)900170

Hyland, F. (2003). Focusing on form: student engagement with teacher feedback. System, 31(2), 217-230. https://doi.org/https://doi.org/10.1016/S0346-251X(03)00021-6

Hyland, F. (2010). Future directions in feedback on second language writing: Overview and research agenda. IJES, International Journal of English Studies, 10(2), 171-182. Retrieved from http://dialnet.unirioja.es/servlet/articulo?codigo=3424361\&info=resumen\&idioma=SPA

Hyland, K., \& Hyland, F. (2006a). Feedback on second language students' writing. Language Teaching, 39(02), 83. https://doi.org/10.1017/S0261444806003399

Hyland, K., \& Hyland, F. (2006b). Second Language Writing Contexts and Issues. (M. H. Long \& J. C. Richards, Eds.). New York: Cambridge University Press.

Ismail, S. A. A. (2010). ESP Students 'Views of ESL Grammar Learning. GEMA Online Journal of Language Studies, 10(3), 143-156.

Jusa, G., \& Kuang, C. H. (2016). Akademia Baru The Effect of Direct Corrective Feedback on the Correct Usage of the Preposition of Time Akademia Baru, 3(1), 109-122.

Karim, K., \& Nassaji, H. (2015). ESL Students ' Perceptions of Written Corrective Feedback : What Type of Feedback do they Prefer and Why? European Journal of Applied Linguistics and TEFL, 4 (1)(January), 5-25.

Kepner, C. G. (1991). An Experiment in the Relationships of Types of Written Feedback to the Development of Second Language Writing Skills. Modern Language Journal, 75(3), 305-313. https://doi.org/10.1111/j.1540-4781.1991.tb05359.x

Lee, I. (2005). Error Correction in the L2 Writing Classroom: What Do Students Think? TESL Cabada Journal, 22(2), 1-18. https://doi.org/https://doi.org/10.18806/tesl.v22i2.84

Listiani. (2017). Students 'Perception toward Teacher' s Written Corrective Feedback in Writing 3 class. Advances in Social Science, Education and Humanities Research (ASSEHR), 109(Aecon), 164-167.

Liu, N., \& Carless, D. (2006). Peer feedback: the learning element of peer assessment. Teaching in Higher Education, 11(3), 279-290. Retrieved from http://www.tandfonline.com/doi/abs/10.1080/13562510600680582

Maharani, M. M. (2017). The Application of Indirect Feedback to Improve Students' Paragraph Writing. Edulite, 2(2), 389-404.

Nakanishi, C. (2007). The Effects of Different Types of Feedback on Revision. The Journal of Asia Tefl, 4(4), 213-244.

Nanni, A., \& Black, D. A. (2017). Student and Teacher Preferences in Written Corrective 
Feedback. The Journal of Asia TEFL, 14(3), 540-547. https://doi.org/http://dx.doi.org/10.18823/asiatefl.2017.14.3.11.540

Onozawa, C. (2010). A study of the process writing approach. Research Note, (10), 153-163. Retrieved from www.kyoai.ac.jp

Park, G. (2010). Preference of Corrective Feedback Approaches Perceived by Native English Teachers and Students. Journal of ASIA TEFL, 7(4), 29-52.

Parr, J. M., \& Timperley, H. S. (2010). Feedback to writing, assessment for teaching and learning and student progress. Assessing Writing, 15(2), 68-85. https://doi.org/10.1016/J.ASW.2010.05.004

Pazaver, A., \& Wang, H. (2009). Asian Students' Perceptions of Grammar Teaching in the ESL Classroom. The International Journal of Language, Society and Culture, (27), 27-35.

Polio, C., Fleck, C., \& Leder, N. (1998). "If I only had more time:” ESL learners' changes in linguistic accuracy on essay revisions. Journal of Second Language Writing, 7(1), 43-68. https://doi.org/10.1016/S1060-3743(98)90005-4

Puengpipattrakul, W. (2014). A process approach to writing to develop Thai EFL students' socio-cognitive skills. Electronic Journal of Foreign Language Teaching, 11(2), 270-284.

Ravand, H., \& Rasekh, A. E. (2011). Feedback in ESL Writing: Toward an Interactional Approach. Journal of Language Teaching and Research, 2(5), 1136-1145. https://doi.org/10.4304/jltr.2.5.1136-1145

Rohmatika, A. (2014). THE EFFECTIVENESS OF PROCESS APPROACHES IN TEACHING WRITING VIEWED FROM STUDENTS ' LEVEL OF CREATIVITY AND ITS IMPLICATION TOWARDS WRITING ASSESSMENT. In J. Nurkamto \& H. Puji Widodo (Eds.), The 61st TEFLIN International Conference UNS Solo (pp. 470-473). Solo: English Education Department Teacher Training and Education Faculty Sebelas Maret University.

Seker, M., \& Dincer, A. (2014). An insight to students' perceptions on teacher feedback in second language writing classes. English Language Teaching, 7(2), 73-83. https://doi.org/10.5539/elt.v7n2p73

Semke, H. D. (1984). Effects of the Red Pen. Foreign Language Annals, 17(3), 195-202. https://doi.org/https://doi.org/10.1111/j.1944-9720.1984.tb01727.x

Seow, A. (2002). The Writing Process and Process Writing. In J. C. Richards \& W. A. Renandya (Eds.), Methodology in Language Teaching (pp. 315-320). Cambridge: Cambridge University Press. https://doi.org/10.1017/CBO9780511667190.044

Setyono, B. (2014). Approaches in Teaching Writing Designed by High School English Teachers in Indonesia. International Journal of Sciences: Basic and Applied Research (IJSBAR), 14(1), 477-494. Retrieved from http://gssrr.org/index.php?journal=JournalOfBasicAndApplied

Shin, S. K. (2008). "Fire your proofreader!" Grammar correction in the writing clas sroom. ELT Journal, 62(4), 358-365. https://doi.org/10.1093/elt/ccm089

Storch, N. (2010). Critical feedback on written corrective feedback research. International Journal of English Studies, 10(2), 29-46. https://doi.org/10.6018/ijes/2010/2/119181

Truscott, J. (1996). The Case Against Grammar Correction in L2 Writing Classes. Language Learning, 46(2), 327-369.

Truscott, J. (2007). The effect of error correction on learners' ability to write accurately. Journal of Second Language Writing, 16(4), 255-272. https://doi.org/10.1016/j.jslw.2007.06.003

Vyatkina, N. (2011). Writing instruction and policies for written corrective feedback in the basic language sequence. L2 Journal, 3(1), 63-92. 
REGISTER JOURNAL

Vol. 12, No. 1, pp.28-48

p-ISSN: 1979-8903; e-ISSN : 2503-040X

DOI: http://dx.doi.org/10.18326/rgt.v12i1.28-48

Website: http://journalregister.iainsalatiga.ac.id/index.php/register/

Wahyuni, S. (2017). The Effect of Different on Writing Quality of College Student with Different Cognitive Styles. Dinamika Ilmu, 17(1), 39-58. https://doi.org/10.21093/di.v17i1.649

Widodo, H. P. (2008). Process-Based Academic Essay Writing Instruction in an EFL Context. Jurnal Bahasa Dan Seni, 36(1), 111-125.

Yamashita, T. (2017). Review of written corrective feedback for L2 development. Journal of Response to Writing, 3(2), 1-7. 